\title{
GYERMEKEK MENTÁLISAN SÉRÜLÉKENY CSALÁDOKBAN
}

\author{
HEgEdüs Judit \\ az Eötvös Loránd Tudományegyetem Pedagógiai és Pszichológiai Karának \\ egyetemi adjunktusa \\ hegedus.judit@ppk.elte.hu
}

Több mint tíz éve dolgozom a gyermekvédelemben, ahol nagyon gyakran találkozom mentálisan beteg, vagy a kötet szóhasználatával élve mentálisan sérülékeny családokkal, szülőkkel. Az évek során szerzett tapasztalatok alapján és a (részben) autodidakta módon összegyüjtött szakmai anyagok segítségével próbáltam tájékozódni ebben a világban jól-rosszul, ennek ellenére - föleg a pályám elején - nagyon gyakran átéltem magárahagyatottságot, bizonytalanságot és az inkompetencia érzését. Nem voltam biztos abban, hogy jól tudok segíteni. Talán ezért is vettem kézbe nagy örömmel és kíváncsisággal $F$. Lassú Zsuzsa által szerkesztett kézikönyvet, mely a mentálisan sérülékeny családokban élö gyermekek megsegítését célozta meg. Elöljáróban szeretném hangsúlyozni, hogy olyan hiánypótló munkáról van szó, amely nagyon sok hasznos információt, ismeretet tartalmaz. A szerzők, név szerint F. Lassú Zsuzsa, Glauber Anna, Hajdu Krisztina, Kolossai Nedda, Rózsáné Czigány Enikö, hazai és nemzetközi szakirodalmak alapján árnyalt képet adnak arról, hogy mi jellemzi a mentálisan sérülékeny családokat, a benne nevelkedő gyermekeket, és bemutatják, hogy a szakembereknek milyen lehetőségei vannak a velük való szakszerü foglalkozásra. Hiánypótló ez a munka abból a szempontból is, hogy a mentális betegségekben érintett személyekkel szembeni elöítéletet igyekszik csökkenteni. Akár akarjuk, akár nem, el kell fogadnunk azt a tényt, hogy a társadalom fél tőlük és kerüli a pszichiátriai betegeket. Elgondolkodtató az a tény, melyre F. Lassú Zsuzsa is felhívta a figyelmet, a mai magyar társadalom jelentős része inkább lakna egy bünöző szomszédságában mint egy pszichiátriai betegében. A pszichiátriák rossz híre, a gyermekpszichiáterek nagyon alacsony száma sem kedvez e csoport társadalmi megitélésének. Mit tesz e könyv az előítéletek csökkentésének érdekében? Az ismeretek közvetítésén túl a pedagógusok körében a tabukat kívánja ledönteni, meg akarja ismertetni az olvasót azzal a világgal, amelyből a - gyakran amúgy is gondot okozó - gyerek jön. Leginkább szemléletmódot akar váltani. Nekem ezért is tetszik nagyon ez a könyv.

Már az első fejezetben „lekenyerezett” F. Lassú Zsuzsa, amikor a címkéző mentális betegség helyett az első olvasatra kissé megfoghatatlan mentális sérülékenység fogalmat értelmezni. Mentálisan sérülékeny családnak nevezzük azokat a családokat, ahol mentális betegség előfordul. A „sérülékenység mindannyiunk 
emberi jellemzője” (14. o.), mindannyian kerülhetünk olyan helyzetbe, amikor „megcsap" a mentális sérülékenység szele, és nagyon szerencsések vagyunk, hogyha nem vonódunk be akaratunktól függetlenül a pszichiátriai betegségekbe. A mentális sérülékenység megjelenésével, érzékelésével kapcsolatos főbb jellemzők közül hadd emeljem ki azokat, amelyekkel személy szerint is nap mint nap találkozom és amit a szerző is kiemelt:

- Hihetetlennek tünik, de a szerző szerint elég három hónap, hogy érzékeljük a mentálisan sérülékeny szülő hatását a gyermek viselkedésén.

- „Elbújnak az otthon falai között” - családi titok, fontos kérdés, hogy egyáltalán kiderül-e, és ha igen, akkor mikor.

- A gyerek arra szocializálódik, hogy neki a mentálisan sérülékeny szülöjét kell támogatnia!

- Folyamatosan növekszik a tünetek intenzitása mind a mentálisan sérülékeny személynél, mind a gyermekeknél.

- A gyermek életkora is döntő: minél fiatalabb annál kedvezőtlenebb a hatása, de a serdülőkorról sem kellene elfeledkezni, hiszen ez az egyik legérzékenyebb fejlődési periódus.

- A szükségletekre való építés elengedhetetlen mind a szülőnél, mind pedig a gyermeknél.

E fejezet talán legfontosabb gondolata, melyet a szerző maga is csupa nagybetủvel emelt ki: a gyermeket nem szabad stabilizáló tényezőként, vagy fontos pszichológiai gyógyító tényezőként, támaszként használni a beteg szülő gyógykezelése során - azaz itt a rendszerabúzus (rendszerbántalmazás, amikor maga a támogató rendszer követ el hibát és ebböl adódóak kerül rosszabb helyzetbe a gyermek) nagyon gyakori jelenségére hívta fel a figyelmet.

Az egyes mentális betegségekkel (depresszió, bipoláris zavar, skizofrénia, szorongásos zavarok, személyiségzavarok, alkohol- és kábítószerfüggés, táplálkozási zavarok) foglalkozó második fejezetben remek logikai sorrendet jelenített meg $F$. Lassú Zsuzsa: elsőként a tünettan és ezen belül a viselkedés, a gondolkodás, az érzelmek és a testi reakciók bemutatására, vizsgálatára került sor, majd elemezte, hogy a betegség miként hat a gyermek életére, végül a beavatkozás alapelveire, föbb támogató stratégiákra tért ki. A fejezetben az elmélyült orvosi és pszichiátriai tudással nem rendelkezők számára is értelmező információk olvashatók, melyek segíthetik a pedagógusokat abban, hogy a legfontosabb jellemzőkkel tisztában legyenek. Mindennek segítségével a gyermek helyzetének megértéséhez kapnak jól hasznosítható, nem annyira a konkrét betegségekhez, mint inkább az általános segítségnyújtásban alkalmazható információkat. Minden bizonnyal kissé leegyszerüsítve jelennek meg a betegségek, de a szerző - helyesen - felhívja a figyelmet arra, hogy mindez csupán a tájékozódást szolgálja. Néha-néha olvasás közben elöjön a szkepticizmusom: gyakran tanácsolja a szerző, hogy a gyermekvédelmi ellátórendszer mozgósítása javallott, de sajnos a mindennapi helyzetekben rendszerint 
szembesülünk azzal, hogy a rendszer tehetetlen, vagy nem akar tenni a probléma megoldása érdekében. A leggyakoribbnak ítélt mentális betegségek közül a hazai tapasztalatokkal összhangban az alábbiak kerültek kiemelésre: depresszió, bipoláris zavar, skizofrénia, szorongásos zavarok, személyiségzavarok, alkohol- és kábítószerfüggés, táplálkozási zavarok.

A segítés során gyakran próbálunk támaszkodni a szülö-gyermek között meglévő kötődésre, ezért is tartom fontosnak, hogy a kötetben megjelent a kötődéssel kapcsolatos elméleti tudás összefoglalása. Jól érzékelhető, ami majd a kötet többi fejezetében is megjelenik, hogy nem egyszerü dolog az általános megközelítést, leírást kapcsolni ehhez a speciális területhez, de ha figyelmesen elolvassuk a fejezetet, a gyakorlatból is jól látható jelenségeket említ $F$. Lassú Zsuzsa a mentálisan sérülékeny családokban élő gyerekeknél:

- a felfedező viselkedés sérülését,

- a félelemmel kapcsolatos tipikus viselkedést,

- a társas kapcsolatok kialakításának nehézségeit.

Mindezeken túl az önszabályozás, a függőség, önbizalom, énhatékonyság, a szorongás, a társas kapcsolatok területén megjelenő deficitekkel is szembesülhetünk. Számomra e fejezet nagyon fontos gondolata a kötődési személy jelentősége. Érdekes volt szembesülni a munkám során is, hogy a gyerek megkeresi azt a személyt, akihez tud kötődni, s itt ne feledkezzünk el arról, hogy ez nagyon gyakran nem a pozitív értékeket hordozó személy. Ez pedig újabb nehézséget okozhat a későbbi életút során. A kötődéssel kapcsolatos problémákból az egyik fontos kiút a gyermekek számára a rugalmasság, a reziliencia lehet. A kötet 4. fejezete, melynek szerzője Glauber Anna, e területtel foglalkozik. A fogalom értelmezését követően a megküzdési mechanizmusokat mutatta be a szerző a tágabb család felelősségét is hangsúlyozva. Bronfenbrenner családökológiai modellje kiváló értelmezési keretül szolgált, felhívva a figyelmet a családi reziliencia fontosságára. A családok segítésére hasznos tanácsokról, nemzetközi jó gyakorlatokról olvashatunk, ugyanakkor némi hiányérzete is lehet az olvasónak, mert a hazai jó példák kevéssé kerülnek bemutatásra (pedig vannak, gondoljunk a Magyar Családterápiás Egyesület vagy akár a Vadaskert Alapítvány tevékenységére).

F. Lassú Zsuzsa másik írásában az intézményi nevelésről mint védőfaktorról írt. Itt sem könnyü megtalálni az egyensúlyt többféle szempontból sem: egyrészt az életkor, másrészt az általános és speciális ismeretek tekintetében. A szerző alapvetően a bölcsődei és az óvodai ellátásra fókuszált, indokként fogalmazta meg, hogy az élet első évei a rugalmasság tényezőit leginkább megalapozó évek. Azonban tudjuk mindannyian, hogy hazánkban még a bölcsődei ellátás sok területen esetleges, a problémák fokozottabban az óvodai és még inkább az iskolai életben jelennek meg. Az intézményi nevelés egyik legföbb feltételeként fogalmazódik meg a tanár mint példakép, aki nemcsak mintát közvetít, hanem rendelkezik olyan módszertani repertoárral (ezekböl hoz is néhány példát a szerzö), amellyel hatékonyan tudja segíteni 
a gyermeket. És nem utolsósorban képes a szülők támogatására is. Ez az alfejezet talán a gyakorló szakemberek számára a legfontosabb, hiszen számos olyan kérdés megválaszolására kapunk támpontot, amely nap mint nap kering a fejünkben:

- Hogyan lehet kommunikálni a szülökkel?

- Hogyan ismerhetem meg őket?

- Meddig terjed a kompetenciám?

A módszereken és alapelveken túl még egy átgondolandó és nagyon gyakran tabuként kezelt témát is taglal a szerző: a pedagógus saját személyes érintettsége és önismerete, valamint elöítélete is nagymértékben befolyásolja a segítés minőségét. Be kell vallanom őszintén, amikor először találkoztam pszichiátriai beteg klienssel gyermekvédelmi munkám során, nemcsak bizonytalanságot éreztem, hanem félelemét is. Félünk attól, amit nem ismerünk: a könyvben bemutatott módszerek és elvek csak akkor müködnek, hogyha felkészültek erre a szakemberek - azonban azt tapasztaljuk, hogy van még mit tennünk ezen a téren. Ez a kézikönyv hasznos kiindulási pont lehet a pedagógusképzés tartalmi megújulásához.

A segítés egyik nagyon fontos módszeréről, a játékról Kolosai Nedda írt. A játék fogalmának értelmezése és a játékelméleti alapok ismertetése jó kiindulópont, ugyanakkor többet tudunk meg általában a játékról, a játékpedagógiai és pszichológiai alapokról, mint konkrétan a mentális sérülékeny családokban nevelkedő gyermekek játéktevékenységéről. Mit játszanak, miért játszanak? Ezek fontos kérdések lehetnek már a tünetek felismerésében, majd a segítésben is. Vitatkoznék a szerző azon megállapításával, hogy a mentálisan sérülékeny szülők gyermekei „nem igényelnek alapvetően más típusú pedagógiai segítséget és munkát „csupán” fokozott odafigyelést és teljes következetességet.” (127. o.) Ha ez így lenne, akkor ez a könyv sem született volna meg. De szerencsére megszületett. Az általánosságban fontos játékpszichológiai összefoglaló fejezetben számomra talán a legérdekesebb rész a családi játékokról szóló alfejezet. Kérdések fogalmazódnak meg: Tényleg nincs szükség a nagyszülők túlóvására? Lehet-e egy pszichiátriai beteg autonóm életvezetésében teljes mértékben bízni? Az eddigi fejezetekben pont arról olvastunk, hogy alapvetően fontos egy stabil pont a gyermek közelében, aki szükség esetén azonnali segítséget tud nyújtani.

Rózsáné Czigány Enikö írása két nagyon érdekes területre fókuszál: a balesetek és a magatartászavarok megjelenését vizsgálta a mentálisan sérülékeny családok gyermekeinél. Korábbi kutatási eredményei nemcsak a balesetek témaköréhez kapcsolhatók, hanem a gyermekbántalmazáshoz is. Érdekes és további kutatásra ösztönző gondolatok fogalmazódtak meg bennem a fejezetet olvasva: a gyermekbalesetek ilyen irányú vizsgálata valóban fontos feltárandó terület lehet. A fejezet másik erőssége a gyakorlatban remekül használható módszerek ismertetése a magatartászavarok korrekciója érdekében. Ilyen például a családlátogatás, a megfigyelés, melyekhez lényeges, hasznos megfigyelési szempontokat rendelt a szerző; az összegző ív, a detektív ív, a fotókkal való munka. Valóban fontos eleme a segító 
munkának a szabályalkotás, amivel kapcsolatban érdemes lett volna a szerződések rendszeréröl bővebben írni. Hasonlóan az előző fejezetekhez itt is szembesülünk azzal, hogy a kisgyermekkor került igazán kidolgozásra.

Az utolsó fejezetben Hajdu Krisztina a gyermekvédelem szemszögéböl foglalkozott a témával - legalábbis a cím ezt ígéri, azonban témáját tekintve inkább a gyermekbántalmazást részletezte a szerző, a gyermekvédelmi rendszer bemutatása inkább leíró jellegű a vonatkozó jogszabályok és szakirodalmak felhasználásával. E kritika ellenére is számos fontos gondolattal találkozhatunk az írásban, a szerző nagyon jól látja a gyermekvédelmi rendszer müködésének anomáliáit, a személyi feltételek, a kompetenciahatárok hiányát. Ennek ellensúlyozására próbálta áttekinteni Hajdu Krisztina a pedagógus teendőit a mentálisan sérülékeny családokban nevelkedő gyerekek megsegítése érdekében: alapvetően a segítő beszélgetésről tudunk meg sok mindent, de azt, hogy konkrétan kihez lehet fordulni, mit is kell tennem pedagógusként, ha pszichiátriai beteg szülővel találkozom, nem tudjuk meg a leírásból. A fejezet végén található esetleírások színesítik a kötet, megmutatják, hogy a szakszerü segítő munkával igenis tudnak müködni a családok. És ez talán a kötet legfontosabb üzenete: van remény ezeknek a családoknak...

Összességében véve egy szakszerű, érdekes és hasznos könyvet készítettek a szerzők, mely igen nagy segítséget nyújthat pedagógusoknak, szociális munkásoknak, szociálpedagógusoknak.

F. Lassú Zsuzsa (szerk., 2011): Gyermekek mentálisan sérülékeny családokban. ELTE Eötvös Kiadó, Budapest, 206 oldal 